\title{
Correlation between hepatic morphology and immunoglobulins and antibodies to Escherichia coli in cirrhosis
}

\author{
HANNE PRYTZ, M. BJØRNEBOE, P. CHRISTOFFERSEN, H. POULSEN, AND \\ F. ØRSKOV \\ From Medical Department B and Department of Clinical Chemistry, Bispebjerg Hospital, \\ Department of Pathological Anatomy, Hvidovre Hospital, and International Escherichia Centre (WHO), \\ Statens Seruminstitut, Copenhagen, Denmark
}

SUMMARY Increased antibody production and hypergammaglobulinaemia in cirrhosis are probably to a large extent due to decreased hepatic extraction of antigens. The decreased extraction is presumably related to changed microcirculation caused by damaged anatomical structure of the liver. It is therefore to be expected that immunoglobulin and antibody levels in serum in cirrhotic patients are related to the degree of certain morphological changes of the liver. This hypothesis has been tested. In 50 patients with cirrhosis, 28 alcoholics and 22 non-alcoholics, the degree of architectural destruction, the degree of fibrosis, the degree of fatty infiltration, and the degree of 'activity' were compared with immunoglobulins $\mathrm{G}, \mathrm{A}$, and $\mathrm{M}$ and $E$. coli 0 antibody levels. The comparison was carried out within each of the aetiological groups. Identical relationships were found in both groups. Patients with completely destroyed lobular architecture had higher levels of $E$. coli 0 antibodies than patients with partly destroyed architecture. Patients with severe fibrosis had higher IgA and $E$. coli 0 antibody levels than patients with moderate or slight fibrosis. Patients with moderate and severe steatosis and patients with no or slight steatosis had the same immunoglobulin and $E$. coli 0 antibody levels. Patients with active cirrhosis had higher IgG levels than patients with inactive cirrhosis. When architectural destruction and fibrosis were combined significantly higher IgG, $\operatorname{IgA}$, IgM, and $E$. coli antibodies were found in the group with the most severe changes. These findings support the hypothesis that immunoglobulin and antibody levels are related to the degree of morphological changes in the liver-namely, destruction of lobular architecture, fibrosis, and 'activity'.

Hepatic extraction of substances normally phagocytised by the Kupffer cells is decreased in cirrhosis of the liver (Halpern et al., 1959; Rankin et al., 1961). In experimental cirrhosis decreased hepatic uptake of antigens is accompanied by increased splenic uptake (Thomas et al., 1973) and increased antibody production (Triger and Wright, 1973). Kupffer cell blockade influences hepatic and splenic uptake as well as antibody production in the same way (Souhami, 1972; Souhami et al., 1975). Normally functioning Kupffer cells destroy the immunogenicity of phagocytised antigens (Inchley, 1969; Franzl, 1972; Archer and Wust, 1973). The decreased hepatic uptake and elimination of antigens resulting in a spillover of antigen to antibody producing sites Received for publication 14 July 1976 such as the spleen is now considered the main cause for the increased antibody production and hypergammaglobulinaemia in cirrhosis (Bjørneboe et al., 1972; Triger et al., 1972; Prytz et al., 1974). The reduction in hepatic uptake of antigens is directly related to the histological severity of experimental cirrhosis in rats (Thomas et al., 1973). The purpose of this study is to investigate if this is true for human cirrhosis as well.

\section{Methods}

Fifty consecutive patients were studied, in whom liver biopsies performed according to the method of Menghini exhibited cirrhosis defined as a diffuse lesion of the liver with regeneration nodules and fibrosis. 
They were divided into two aetiological groups, alcoholic and non-alcoholic. Alcoholic cirrhosis is cirrhosis in patients who admitted to have been drinking more than $50 \mathrm{~g}$ ethanol a day for more than five years. At the same time as the biopsy was performed serum immunoglobulin concentrations were determined by electrophoresis in antibodycontaining agarose gel (Laurell, 1966). E. coli 0 group antibodies in serum were measured by agglutinin titration as described elsewhere (Bjørneboe et al., 1972). Each serum was tested with 12 common 0 group antigens. A titre of $1: 40$ was considered to be positive. The result of the $E$. coli antibody determinations was indicated as the number of positive reactions per serum.

The assessment of the liver biopsies was performed without knowledge of the clinical data. The degree of destruction of lobular architecture was indicated as partly or completely destroyed lobular architecture depending on the presence or absence of demonstrable remnants of lobules in the biopsy.

The fibrosis was registered semi-quantitatively according to the amount of connective tissue related to the amount of parenchyme in the following manner: slight fibrosis (+) when the fibrous tissue surrounding the parenchymal nodules was seen as slender septa, moderate fibrosis $(++)$ if the septa were broad, and severe $(+++)$ when large confluent areas of fibrosis were predominant.

The degree of histological activity (inactive or active) was graded on the basis of the amount of liver cell necroses and the mesenchymal reaction on these. The liver cell necroses (focal, piecemeal, alcoholic hepatitis, lipogranulomas, and the accompanying mesenchymal reaction) were registered and the cases were graded as inactive or active in the following manner: inactive-none or only one or two liver cell necroses per nodule; active-more than two liver cell necroses per nodule.

The fatty changes were quantified in the following manner: + - the biopsy specimens contain fatty vacuoles, but on an average in less than one third of the cells; ++ -the specimens contain fatty vacuoles in one-third or more but in less than two-thirds of the cells; +++ -the specimens contain fatty vacuoles in two-thirds or more of the cells.

The following analysis was carried out in each of the two aetiological groups. Immunoglobulin G, A, and $M$ and $E$. coli antibodies expressed as number of positive reactions have been compared in subgroups with different degrees of each morphological abnormality.

\section{Results}

The patients comprised 27 males and 23 females. Twenty-eight were chronic alcoholics, while 22 patients denied ethanol abuse. No patient had clinical evidence of biliary tract infection but two had urinary tract infections with $E$. coli-that is, growth of more than $10^{5} \mathrm{E}$. coli per ml midstream urine. The age range in years was, for the 28 alcoholics, 33-74 years (median 55 years) and, for the 22 non-alcoholics, 22-81 years (median 63 years). Fifteen patients had ascites and 4 had oesophageal varices demonstrated by radiography. The main histological features of the liver biopsies are shown in Table 1. Completely destroyed lobular architecture was more frequent in alcoholic than in non-alcoholic cirrhosis. Moderate and severe fatty change was seen in $43 \%$ of the alcoholics, whereas it was never demonstrated in the non-alcoholics. Active cirrhosis

Table 1 Main histological features of liver biopsies from 50 cases of cirrhosis*

\begin{tabular}{|c|c|c|c|c|c|c|c|c|}
\hline & \multicolumn{2}{|c|}{ Destruction of architecture } & \multicolumn{2}{|l|}{ Fibrosis } & \multicolumn{2}{|c|}{ Steatosis } & \multicolumn{2}{|l|}{ Activity } \\
\hline & Partly & Completely & $+1+t$ & $+t+$ & $0 /+$ & $++1+t+$ & Inactive & Active \\
\hline $\begin{array}{l}\text { Total } \\
\text { Alcoholic cirrhosis } \\
\text { Non-alcoholic cirrhosis } \\
\text { Differences } \dagger\end{array}$ & $\begin{array}{l}27 \\
11 \\
16 \\
2 P\end{array}$ & $\begin{array}{r}23 \\
17 \\
6\end{array}$ & $\begin{array}{l}29 \\
13 \\
16\end{array}$ & $\begin{array}{r}21 \\
15 \\
6\end{array}$ & $\begin{array}{l}38 \\
16 \\
22 \\
2 P\end{array}$ & $\begin{array}{r}12 \\
12 \\
0\end{array}$ & $\begin{array}{r}31 \\
22 \\
9 \\
2 P<\end{array}$ & $\begin{array}{r}19 \\
6 \\
13\end{array}$ \\
\hline
\end{tabular}

* For definition of the histological qualities, see text.

†Fisher's exact test.

Table 2 Immunoglobulins and E. coli 0 antibodies in serum of 28 patients with alcoholic cirrhosis and 22 patients with non-alcoholic cirrhosis

\begin{tabular}{|c|c|c|c|c|c|}
\hline & \multicolumn{2}{|c|}{ Alcoholic cirrhosis $(N=28)$} & & \multicolumn{2}{|c|}{ Non-alcoholic cirrhosis $(N=22)$} \\
\hline & Median & Range & & Median & Range \\
\hline $\begin{array}{l}\text { IgG } \mathbf{g} / 1 \\
\text { IgA } g / 1 \\
\text { IgM } g / 1 \\
\text { No. of positive antibody reactions }\end{array}$ & $\begin{array}{r}14 \cdot 8 \\
7 \cdot 1 \\
1 \cdot 1 \\
4\end{array}$ & $\begin{array}{l}7 \cdot 2-26 \cdot 0 \\
2 \cdot 3-24 \cdot 0 \\
0 \cdot 5-3 \cdot 2 \\
0-11\end{array}$ & $\begin{array}{l}2 \mathbf{P}<0.02 \\
2 \mathbf{P}<0.02 \\
\text { N.S. } \\
2 \mathbf{P}<0.01\end{array}$ & $\begin{array}{l}20.6 \\
3.9 \\
0.9 \\
2\end{array}$ & $\begin{array}{l}9 \cdot 5-43 \cdot 2 \\
1 \cdot 9-12 \cdot 0 \\
0 \cdot 3-12 \cdot 0 \\
0-7\end{array}$ \\
\hline
\end{tabular}


was more often seen in non-alcoholics. The immunoglobulin concentrations and $E$. coli antibody levels in the two groups are shown in Table 2. IgG levels are higher in non-alcoholic cirrhosis, whereas IgA and $E$. coli antibody levels are higher in alcoholic cirrhosis. The relationship between the different morphological features and immunoglobulin concentrations and $E$. coli antibody levels within each aetiological group are shown in Tables 3 and 4 .

With regard to the destruction of lobular architecture, $E$. coli levels were highest in the groups with completely destroyed architecture in alcoholics as well as in non-alcoholics. However, the difference was significant only in the alcoholic group. With regard to fibrosis IgA levels were significantly higher in the groups with severe fibrosis in the alcoholics as well as in the non-alcoholics. There were significant differences between IgG and the number of $E$. coli reactions in the group of alcoholics but not in the non-alcoholics. With regard to histological 'activity' IgG levels were significantly higher in active cirrhosis in the alcoholics as well as in the non-alcoholics. IgA was also higher in both groups with active cirrhosis, but only significantly so in the nonalcoholics. Finally, when immunoglobulins and $E$. coli antibody levels were compared in two groups of alcoholic cirrhosis-patients with completely destroyed lobular architecture and +++ fibrosis, and patients with less severe morphological changesIgG, IgA, IgM and $E$. coli antibodies were significantly higher in the former group (Table 5). The comparison could not be made in the non-alcoholic group because of the small number of cases. Alcoholic patients with severe or moderate steatosis had no

Table 3 Relationship between degree of architectural destruction, fibrosis, or activity and immunoglobulins or E. coli 0 antibodies in 28 patients with alcoholic cirrhosis

\begin{tabular}{|c|c|c|c|c|c|c|c|c|c|}
\hline & \multicolumn{2}{|c|}{ Destruction of architecture } & & \multicolumn{2}{|l|}{ Fibrosis } & & \multicolumn{2}{|c|}{ Activity } & \\
\hline & Complete & Partial & & +++ & $+1++$ & & Active & Inactive & \\
\hline $\begin{array}{l}\text { No. of patients } \\
\text { IgG* g/l } \\
\text { IgA } \mathbf{g} / 1 \\
\text { IgM } \mathbf{g} / \mathbf{1} \\
\text { No. of positive } \\
\text { antibody } \\
\text { reactions }\end{array}$ & $\begin{array}{r}17 \\
15 \cdot 8 \\
7 \cdot 8 \\
1 \cdot 3\end{array}$ & $\begin{array}{l}11 \\
13 \cdot 1 \\
5 \cdot 7 \\
0 \cdot 7\end{array}$ & $\begin{array}{l}\text { N.S. } \\
\text { N.S. } \\
\text { N.S. }\end{array}$ & $\begin{array}{r}15 \\
20 \cdot 7 \\
8 \cdot 6 \\
1 \cdot 3\end{array}$ & $\begin{array}{l}13 \\
10 \cdot 5 \\
4 \cdot 1 \\
0.9\end{array}$ & $\begin{array}{l}2 \mathrm{P}<0.01 \\
2 \mathrm{P}<0.01 \\
\text { N.S. }\end{array}$ & $\begin{array}{r}6 \\
17 \cdot 3 \\
7 \cdot 7 \\
1 \cdot 2\end{array}$ & $\begin{array}{r}22 \\
13 \cdot 0 \\
6 \cdot 4 \\
1 \cdot 1\end{array}$ & $\begin{array}{l}2 \mathrm{P}<0.05 \\
\text { N.S. } \\
\text { N.S. }\end{array}$ \\
\hline
\end{tabular}

* Median values are given.

†Wilcoxon rank sum test.

Table 4 Relationship between degree of architectural destruction, fibrosis, or activity and immunoglobulins or E. coli 0 antibodies in 22 patients with non-alcoholic cirrhosis

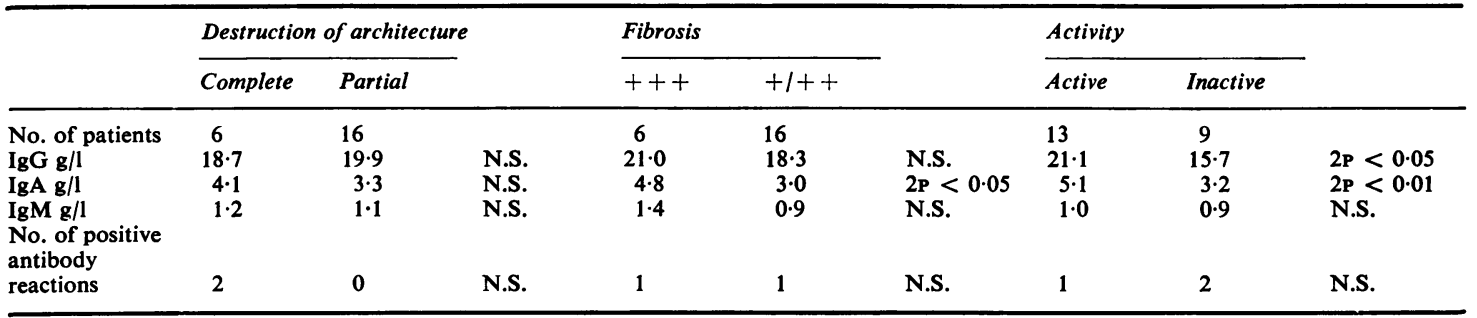

Table 5 Relationship between degree of morphological changes of liver and immunoglobulins and $\mathrm{E}$. coli 0 antibodies in 28 cases of alcoholic cirrhosis

\begin{tabular}{|c|c|c|c|}
\hline & $\begin{array}{l}\text { Severe morphological changes* } \\
(N=12) \\
\text { Median }\end{array}$ & & $\begin{array}{l}\text { Less severe morphological } \\
\text { changest }(N=10) \\
\text { Median }\end{array}$ \\
\hline
\end{tabular}

+++ Fibrosis and completely destroyed lobular architecture.

†All others. 
significantly different $E$. coli antibody or Ig levels from patients with slight or no steatosis (figures not shown).

\section{Discussion}

This study demonstrates that a relationship can be found between certain changes in the liver structure in alcoholic and non-alcoholic cirrhosis, and immunoglobulins and E. coli antibody levels. The results cannot be biased by aetiological factors, as the data have been analysed within each aetiological group. Destruction of lobular architecture influences $E$. coli antibody levels, fibrosis influences IgA and $E$. coli antibody levels, and 'activity' influences IgG levels. Steatosis of different degrees has no effect on immunoglobulins or $E$. coli antibody levels in alcoholic cirrhosis.

The study suggests that structural changes in the liver have an effect on immunoglobulin and $E$. coli antibody production in cirrhosis. The various morphological changes do not influence the different Ig classes and $E$. coli antibodies with the same intensity. However, when the alcoholic cases are divided into two groups-those with total architectural destruction and severe fibrosis, and those with less severe changes-all Ig classes and E. coli antibody levels are higher in the former group. Structural changes may influence antibody production through changes in the hepatic extraction of antigens. In human alcoholic cirrhosis an increase of individual cellular reticuloendothelial phagocytic activity was found, while the total reticuloendothelial phagocytic capacity was reduced. This capacity was closely correlated with reticuloendothelial perfusion (Cooksley et al., 1973). Reduced hepatic uptake of antigens in human cirrhosis is therefore most probably caused by decreased sinusoidal blood flow. This has recently been shown also in animal experiments (Lloyd and Triger, 1975). Architectural destruction with formation of regenerative nodules, fibrosis, and 'activity' may all influence the microcirculation of the liver and reduce the sinusoidal blood flow (Leevy et al., 1958; Shaldon et al., 1961; Preisig et al., 1966; Rappaport et al., 1966; Reynolds et al., 1969).

Findings of the relationship between liver morphology and IgG and E. coli antibodies can be explained, if a decreased extraction of antigens in the cirrhotic liver with these morphological changes is supposed. The increase in IgA levels is more difficult to account for. Part of the circulating $\operatorname{IgA}$ is synthesised by plasma cells in the small intestinal mucosa (Vaerman and Heremans, 1970). It is unlikely that this synthesis can be influenced by changes in liver morphology. Part of IgA is, however, produced in the bone-marrow and this part of $\operatorname{IgA}$ may be related to liver morphology. Higher doses of antigen are required to elicit specific IgA than IgG responses, but certain increments in antigenic doses appear to cause a greater rise in the number of specific IgA antibody producing cells than IgG producing cells (Benner et al., 1974). In the present study the relationship between liver morphology and increased IgA may be related to such critical increments in antigenic spillover from the liver.

We have in an earlier study shown that the presence of steatosis also in patients without cirrhosis increases E. coli antibody levels (Prytz et al., 1973). That the present study does not demonstrate a relationship between different degrees of steatosis and $E$. coli antibody levels may indicate that the impact of steatosis on the microcirculation of the cirrhotic liver is so little that variations in the degree of steatosis are not reflected in the extraction of antigen.

This study was supported by Kong Christian X's Fond, F. L. Smidth \& Co. A/S Jubilaeumsfond and Statens laegevidenskabelige forskningsråd.

\section{References}

Archer, S. J., and Wust, C. J. (1973). Comparison of immunogenic RNA extracted from peritoneal exudate cells and Kupffer cells of the rat. Annals of the New York Academy of Sciences, 207, 241-250.

Benner, R., Meima, F., Van der Meulen, G., and van Ewijk, W. (1974). Antibody formation in mouse bone marrow. 3 . Effects of route of priming and antigen dose. Immunology, 24, 747-760.

Bjørneboe, M., Prytz, H., and Ørskov, F. (1972). Antibodies to intestinal microbes in serum of patients with cirrhosis of the liver. Lancet, 1, 58-60.

Cooksley, W. G. E., Powell, L. W., and Halliday, J. W. (1973). Reticuloendothelial phagocytic function in human liver disease and its relationship to haemolysis. British Journal of Haematology, 25, 147-164.

Franzl, R. E. (1972). The primary immune response in mice. 3 . Retention of sheep red blood cell immunogens by the spleen and the liver. Infection and Immunity, 6, 469-482.

Halpern, B. N., Biozzi, G., Péquignot, G., Delaloye, B., Stiffel, C., and Mouton, D. (1959). Mesure de la circulation sanguine du foie et de l'activité phagocytaire du systèmeréticuloendothélial chez le sujet normal et le sujet cirrhotique. Pathologie et Biologie, 7, 1637-1653.

Inchley, C. J. (1969). The activity of mouse Kupffer cells following intravenous injection of $\mathrm{T}_{4}$ bacteriophage. Clinical and Experimental Immunology, 5, 173-187.

Laurell, C. B. (1966). Quantitative estimation of proteins by electrophoresis in agarose gel containing antibodies. Analytical Biochemistry, 15, 45-52.

Leevy, C. M., Zinke, M., Baber, J., and Chey, W. Y. (1958). Observations on the influence of medical therapy on portal hypertension in hepatic cirrhosis. Annals of Internal Medicine, 49, 837-851.

Lloyd, R. S., and Triger, D. R. (1975). Studies on hepatic uptake of antigen. 3. Studies of liver macrophage function in normal rats and following carbon tetrachloride administration. Immunology, 29, 253-263. 
Preisig, R., Rankin, J. G., Sweeting, J., and Bradley, S. E. (1966). Hepatic hemodynamics during viral hepatitis in man. Circulation, 34, 188-197.

Prytz, H., Bjørneboe, M., Ørskov, F., and Hilden, M. (1973). Antibodies to Escherichia coli in alcoholic and nonalcoholic patients with cirrhosis of the liver or fatty liver. Scandinavian Journal of Gastroenterology, 8, 433-438.

Prytz, H., Bjørneboe, M., Staehr Johansen, T., and Ørskov, F. (1974). The influence of portosystemic shunt operation on immunoglobulins and Escherichia coli antibodies in patients with cirrhosis of the liver. Acta Medica Scandinavica, 196, 109-112.

Rankin, J. G., Playoust, M. R., and Beal, R. W. (1961). Significance of alterations in extraction and distribution of colloidal chromic phosphate in patients with liver disease. Journal of Laboratory of Clinical Medicine, 58, 920-926.

Rappaport, A. M., Black, R. G., Lucas, C. C., Ridout, J. H., and Best, C. H. (1966). Normal and pathological microcirculation of the living mammalian liver. Revue Internationale d'Hépatologie, 16, 813-828.

Reynolds, T. B., Hidemura, R., Michel, H., and Peters, R. (1969). Portal hypertension without cirrhosis in alcoholic liver disease. Annals of Internal Medicine, 70, 497-506.

Shaldon, S., Chiandussi, L., Guevara, L., Caesar, J., and
Sherlock, S. (1961). The measurement of hepatic blood flow and intrahepatic shunted blood flow by colloidal heat-denatured human serum albumin labelled with $\mathbf{I}^{\mathbf{1 3 1}}$. Journal of Clinical Investigation, 40, 1346-1354.

Souhami, R. L. (1972). The effect of colloidal carbon on the organ distribution of sheep red cells and the immune response. Immunology, 22, 685-694.

Souhami, R. L., Addison, I. E., and Bradfield, J. W. B. (1975). Increased antibody production following depression of hepatic phagocytosis. Clinical and Experimental Immuno$\log y, 20,155-159$.

Thomas, H. C., McSween, R. N. M., and White, R. G. (1973). Role of the liver in controlling the immunogenicity of commensal bacteria in the gut. Lancet, 1, 12881291.

Triger, D. R., Alp, M. H., and Wright, R. (1972). Bacterial and dietary antibodies in liver disease. Lancet, 1, 60-63.

Triger, D. R., and Wright, R. (1973). Studies on hepatic uptake of antigen. 2. The effect of hepatotoxins on the immune response. Immunology, 25, 951-956.

Vaerman, J. P., and Heremans, J. F. (1970). Origin and molecular size of immunoglobulin-A in the mesenteric lymph of the dog. Immunology, 18, 27-38. 